\title{
Research Handbook on Islamic Law and Society
}

\author{
Nadirsyah Hosen, ed. \\ Cheltenham, UK: Edward Elgar Publishing, 2018. 485 pages.
}

The premise of the adaptability, flexibility, and compatibility of Islamic normative teachings ( $\operatorname{shari}^{-} a$ ) to new social contexts is already documented by many scholars, including John Bowen's On British Islam: Religion, Law, and Everyday Practice in Sharia Councils and Michael G. Peletz's Islamic Modern: Religious Courts and Cultural Politics in Malaysia. Unlike those works, this textbook is organized by theme which provides a unique contribution to our understanding of the overall function of contemporary Islamic law. Such an approach shows that the 'right' answer in one country is not necessarily the 'right' solution in another Muslim community, which explains the diverse application of Islamic law. The book challenges Wael Hallaq's observation that the modern codification of Islamic law resulted in the absence of hermeneutical possibilities or led to a single mode of judicial application. Perhaps Hallaq's proposition is accurate if we examine the function of Islamic law in a specific country. Nevertheless, the book provides concrete examples of the administrative and interpretive techniques of 'neo-ijtihād' today.

The collection aims to provide an overview of how Islamic law is practiced differently in various contexts and circumstances. It brings together the study of Islamic legal discourse with historical, anthropological, and sociological research on Islamic law. It addresses six themes in 18 chapters, covering 22 countries by twenty contributors specialized in Islamic law and 
social studies. In the first part, "Family Law and Courts", the contributors discuss the function of Islamic law inside and outside the courtrooms in Muslim and non-Muslim countries, the application of the Islamic concept of kafäla (child custody) in the West, and the 'best interests of the child' in the Libyan legal system. Ann Black's chapter on the function of family law in post-colonial Singapore and Australia explains the ways in which Islamic law functions differently in response to various circumstances. Similarly, Arif Jamal argues that Singapore seems to be a more Islamic law friendly-country due to its 'legal pluralism' than the UK, yet the ad hoc function of Islamic law in the latter is more viable due to its "facilitative environment." The section highlights the impact of the prevailing culture on Islamic legal hermeneutical possibilities. For example, Ali Omar Ali Mesrati concludes, "the official interpretation of the law is influenced by the local culture, specifically the Malikiyah 'brand' of Islam" (119).

The articles in the second part, "Property and Business", discuss the (in)compatibility of Islamic law and domestic law. The contributors shed light on land ownership laws in Iran, how Islamic banking in Bangladesh is un-Islamic compared to the conventional banking systems, and whether or not the safety rights of workers in Bangladesh are Islamic. This section speaks to Muslims' efforts in showing the (non)conformity of Islamic law with the post-colonial labor and financial legal systems. One the one hand, S.M. Solaiman states, "Islamic principles are in no means in conflict with the spirit of CSR [corporate social responsibility] currently prevailing in the globe, especially in the developed world, in the era of 'corporate tyranny" (158); similarly, Hossein Esmaeili concludes that "both Islamic law and Iranian law have recognized and protected private ownership under Islamic fiqh" (197). On the other hand, Afraza Begum argues, "the ways in which IB [Islamic Banks] function in Bangladesh is fundamentally flawed and need to be reviewed to achieve the pertinent goals of Shari'ah" (160).

In part three, "Criminal Law and Justice", the contributors examine the punitive and restorative types of justice in Saudi Arabia, Malaysia, and Pakistan. They suggest substantial amendments in the Islamic legal systems to meet the needs of the new context. Through examining corporate crimes in Saudi Arabia, Mohammed Alsubaie suggests that the government should establish more effective commercial courts that deal with such crimes. Similarly, Faisal Kutty describes the apostasy and blasphemy laws in Pakistan and Malaysia as "untenable in the modern period" (249). Likewise, the authors of the article "Restorative Justice in Islamic Law" call for the 
development and harmonization of the criminal justice system in the civil and $\operatorname{sharī}^{\complement} a$ laws in Malaysia.

In part four, "Ethics, Health, and Sciences", contributors explore women-related health issues such as abortion and child marriage in Tunisia and Saudi Arabia, the impact of modernity on fatwa collections on health matters such as organ transplants in Indonesia, and the politics of labeling halāl food production in Sydney, Australia. Nurussyariah Hammado argues that traditional cultural and social norms of a society are the sources of discrimination against women. She observes that due to its continual adaptation, Tunisia improved in the areas of women's rights, whereas in the strict polity of Saudi Arabia, changes are coming slowly but steadily-and inevitably, due to the impact of globalization. Nadirsyah Hosen proposes 'collective ijtihād' as a modern scholarly approach to better answer the new health issues facing Muslims in Indonesia. Furthermore, Richard Mohr reemphasizes the significance of context and the fact that law, religion, and science should be in conversation before taking any critical decision about food consumption. "Neither law, nor science, nor religion is a stand-alone" (326).

In part five, "Arts and Education", the authors discuss figurative representation in Islamic art and how it varies throughout Muslim history; the presence of non-Arabic yet Islamic music in West Java, in Indonesia; and the rights of women to access the university education in Saudi Arabia. Through examining artistic representation in Islam, Mia Corbett observes that "the primary texts of Islamic law are living, dynamic texts that are open to different interpretations across contemporary nation states, religious communities and individuals" (349). Neneng Lahpan points out that the debate about the lawfulness of Islamic music in Indonesia is not only religious but also political, social, and cultural. Moreover, Maan Abdul Haq Khutani points out that Islamic law is compatible with international human rights in protecting Saudi women's right to education. However, he invites the Saudi government to review its policies and systems concerning women's rights to work and education.

In the last part, "Community and Public Spheres", Richard Burgess suggests a successful model of practicing Islam in Bosnia and Hercegovina, which includes female participation in society and dialogue with other national communities. The final chapter in the collection turns again to the impact of modernity on religious edicts and sermons in Indonesia and Malaysia. Muhamad Ali argues that "although colonial regimes did not 
exercise direct control on the context of the sermon and edict, they created new circumstances which forced the preachers to adapt" (429). It offers another compelling example of how postcolonial contextualists approach and reinterpret the religious tenets to fit the new context.

Indeed, Islamic law seems to be flexible in these examples; it functions differently in various contexts. However, the collection does not discuss the hermeneutical theory of Islamic law; it is restricted to the (im)possibility of its application in a specific context. It is more or less a triumph of contextualists' reinterpretations over the literalists among Muslim legal professionals. In other words, socio-ethico-legal constraints determine the juristic interpretation, which is an active force distinct from the Muslim scriptures (Qur'an and Hadith), that shapes what a legal expert can or cannot say. That said, not all the chapters enhance the main premise of the collection, which is centered around the function of Islamic law today. For example, the articles in part two are more authoritative than descriptive or analytical. Furthermore, through showing the flexibility and adaptability Islamic law in response to modernity, the essays of this volume assume that medieval Islamic law was a rigid and unchangeable code. This assumption could be contested as it overlooks the various practices and prolific production of medieval Islamic jurisprudence, let alone the common practices of the four Sunni schools of jurisprudence during the Mamluk era in Syria and Egypt. The collection neither provides a new jurisprudential theory nor successfully challenges an existing one.

Nevertheless, the unique contribution of the book lies in the vast array of its themes, case studies, and countries that these articles cover. It is a survey of the application of Islamic law in Eastern and Western societies, court sittings, and public discourse. The collection demonstrates well how contemporary Muslim jurists (contextualists) show flexibility in their interpretation of the legal issues. It is a necessary read not only for scholars and students of Islamic law but also for those who are interested in the present-day function of $\operatorname{sharì~}^{\complement} a$ in Muslim communities.

Ossama A.S. Abdelgawwad

Assistant Professor

Department of Theology

Valparaiso University, Valparaiso, IN 